Irmina Gadowska

(1) https://orcid.org/0000-0001-8378-942X

Institute of Art History

University of Łódź

irmina.gadowska@uni.lodz.pl

\title{
THE INTERIOR OF THE PRE-BURIAL HOUSE FROM THE NEW JEWISH CEMETERY IN ŁÓDŹ. REMARKS ON ITS ARCHITECTURE, FUNCTION AND STYLE*
}

\begin{abstract}
The development of exact, natural and medical sciences that began in the Enlightenment affected many areas of everyday life, including attitudes to death and funeral rituals. This interest in issues related to the eschata was reflected in changing practice which significantly shaped legal regulations. The structure of metropolitan Jewish necropolises established since the late 18th century and transformation of cemetery architecture highlight the development of sepulchral culture, reflect functional innovations and stylistic changes, as well as the capabilities and requirements of Jewish communities operating in a non-Jewish environment. In the 19th century, through the introduction of new burial rituals, modern forms of grave monuments, representative buildings and park-like appearance, the cemetery becomes a representative place. This paper analyses the interior of the pre-burial house in the new Jewish cemetery in Łódź, taking into account the relationship between the applied architectural solutions and the purpose of the site, as well as the relationship between its function and style. In Jewish historical discourse, the issue of style as a tool for manifesting national identity or the degree of acculturation was primarily associated with synagogue architecture. The case of the pre-burial house from Łódź proves that research on ceremonial buildings erected in Jewish cemeteries may also help to determine the direction and nature of cultural transformation.
\end{abstract}

Keywords: Jewish cemetery, Jewish architecture, Adolf Zeligson, sepulchral art, architecture in Poland, pre-burial houses, Moorish style

* I would like to thank Dr Sergey Kravtsov (Hebrew University of Jerusalem) for his valuable comments that proved helpful in writing this article 
The wave of Enlightenment rationalism developing from the mid-18th century that swept through the relics of the French ancient regime, giving way to republican virtues and the bourgeois order, initiated irreversible changes in social and economic life all over Europe. Progressive ideas led to the development of a new model of religiosity, civic attitudes and everyday functioning in the capitalist system. The transformation affected various groups to varying degrees and with varying strength, and its scope also impacted Jewish circles, especially the big-city bourgeoisie and intelligentsia. The social turn caused a profound transformation of the religious rituals and culture of European Jews, redefining the meaning and functions of traditional institutions such as the community, the synagogue and the cemetery. In the case of newly established necropolises, the divergence between tradition and reforms advocated by the supporters of modernisation manifested itself primarily in spatial arrangement and, perhaps to a greater extent, in cemetery architecture: monuments, mausoleums and preburial houses. A metamorphosis of the latter was a clear indication of a desire to organize rituals related to burial and give them a rational, administrative dimension, which was supposed to lead to secularisation of the rite, having been so far the domain of religious institutions. The above-mentioned aspirations concerned not only Jewish facilities, but were particularly problematic in the case of national minorities, whose survival depended on the strength of the community and creation of identity bonds, given that for centuries religion had been the most solid bond of the Jewish diaspora.

Advances in the exact and natural sciences, as well as medicine that began in the Enlightenment were bound to have some effect on attitudes to death, dying and funeral rituals. Interest in the eschata was reflected in literature, philosophy and theology, but also in changing practice which significantly shaped legal regulations. The layout and architecture of cemeteries depict the development of Jewish sepulchral culture, reflecting functional innovations and stylistic transformations, as well as the possibilities and requirements of Jewish communities operating in a non-Jewish environment. ${ }^{1}$ What seems interesting in this context is the issue of new Jewish metropolitan cemeteries which, from the beginning of the 19th century, were a testimony to the power of emancipation of the Jewish bourgeoisie. A comparison of the largest sites in Central and Eastern Europe reveals significant differences in their spatial arrangement and the erected buildings, as well as in the architecture of pre-burial houses and monuments. The conceptual difference resulted from the geographical location or,

1 U. Knufinke, Jewish cemeteries in 19th century Germany between "Tradition" and "Assimilation": A paradigmatic development for central Europe? in: Jewish Space in Central and Eastern Europe. Day-to Day History, ed. J. Šiaučiunaitè-Verbickienè, L. Lempertienè, Cambridge Scholar Publishing, Newcastle UK, 2007, p. 75. 
more precisely, from local conditions, above all from the degree of assimilation and attachment to tradition. Thus, German cemeteries became the models of modern necropolises, while Eastern European "grave houses" can be described as a kind of a battleground between tradition and modernisation. This battle was fought both in the field of implementing new, functional and hygienic solutions, and of choosing the architectural costume which was supposed to convey a specific message at the turn of the 20th century. An example of such a site is the new Jewish cemetery on Bracka Street in Łódź. The architecture of the pre-burial house located there reflects the dilemmas of the big-city Jewish community at the threshold of modernity - at a time when the internal conflict between the followers of Conservative, Orthodox and Reform Judaism started to be accompanied by a wave of growing anti-Semitism and the need to define one's place in the local community. The interior design solutions chosen by the architect, Adolf Zeligson (1867-1919) ${ }^{2}$, were an attempt to meet the challenges of the contemporary world, while the historicising and orientalising details were aimed to give a clear identity statement, becoming a part of the public architecture of Jewish Łódź.

\section{Pre-burial houses - the origins and functions}

The first pre-burial houses were only used for ritual washing of a dead body and dressing it in burial clothes. These activities could (and often did) take place in a deceased person's house, but since burial sites were located far away from towns and settlements, and the deceased had to be transported there, erecting small buildings adapted to ritual activities in or near a cemetery was a convenient solution to prevent the re-contamination of corpses. In Europe, the oldest buildings of this type have been preserved in the south-western part of Germany (Franconia, Hesse, Swabia). Purification houses (Tahara) dating from the 17th to the first half of the 19th century were small in volume and modestly equipped. ${ }^{3}$ They were erected on the edge of cemeteries, close to

2 Adolf Zeligson (1867-1919), architect, graduate of the School of Crafts in Łódź and Institute of Civil Engineers in St. Petersburg. From 1891, he ran a technical office in Łódź. In 1906, he went to Paris and in 1907 to Moscow. After the Bolshevik revolution, he returned to Poland and died in Warsaw in 1919. See more: K. Stefański, Ludzie, którzy zbudowali Łódź. Leksykon architektów i budowniczych miasta (do 1939 roku), Księży Młyn, Łódź 2009, pp. 182-185; A. Kempa, M. Szukalak, Żydzi dawnej Łodzi. Stownik Biograficzny, vol. 2, Oficyna Bibliofilów, Łódź 2002, p. 141.

3 U. Knufinke, Jüdische Friedhofsbauten um 1800 in Deutschland: Architektur als Spiegel der Auseinandersetzungen um Haskala<<Emanzipation $\rangle>$ und $\langle<$ Assimilation $\rangle>$, "Pardes. Zeitschrift der Vereinigung für Jüdische Studien" 2005, no 2, pp. 71-72. According to the findings of Urlich Knufinke, the oldest existing Jewish pre-burial house in Germany is located in the cemetery of Worms. It was put into use in 1625 . Unfortunately, its original furnishings have not been preserved. 
the wall or fence. Inside, there were stone tables for washing dead bodies and hearths for heating water. The buildings were unmarked, devoid of symbols indicating their function and, unlike Christian chapels, their function was only ritual. Most of them contained only one room intended for the ablution of the deceased. ${ }^{4}$ At the same time, houses with more rooms were built: their functions went beyond the washing of a corpse. They contained prayer rooms for funeral service fraternities or separate spaces where persons excluded from the local community could stay. ${ }^{5}$ An example of such a building is the pre-burial house in the cemetery in Fürth (Bavaria) ${ }^{6}$, which does not exist today. Its appearance is known thanks to an engraving by Johann Alexander Boener from 1705 and another one by Paul Christian Kirchner from 1734. Both depict a separate fenced-off area adjacent to the side wall of a pre-burial house, intended for Cohanim who were forbidden to remain in close proximity to the deceased (under the same roof). In pre-burial houses and prayer rooms built next to them in the 19th and 20th centuries, the concept of a separate room for priests was implemented by locating a roofed niche inside, introducing an arcade connector between the buildings, or designing a separate room covered with another roof. ${ }^{7}$

In the second half of the 18th century, fear of disease and especially of the spread of the plague was a stimulus to introduce new burial regulations, independent of religion. The practice of burial in churches or in their immediate vicinity, which was accepted by Christians, was restricted and church cemeteries were closed or liquidated. Due to religious commandments and local restrictions, Jews usually buried their dead outside the city, so the new regulations were not particularly severe for them, although they also had to leave some cemeteries located near synagogues. This was the case, for example, in the Jewish Town of Piotrków ${ }^{8}$ where burials were organized in accordance

4 Examples of one-room purification houses are buildings from Kleinbardorf, Mühlhausen, Kleinsteinach and Ermetzhofen, erected between 1697 and the end of the 18th century. Cf. U. Knufinke, Jüdische... p.73.

5 Ibid., p. 74.

6 The Fürth cemetery was founded in 1607 and steadily expanded in the following years. By 1936, more than 20,000 people had been buried there. The first pre-burial house dates back to the end of the 18th century. After its destruction, new buildings were erected at the same site twice more, the last of which, being an example of modern cemetery architecture with a prayer room, waiting room and a room for the preparation of the deceased, was demolished in 1938. Cf. M. Berthold-Hilpert, Jüdisches Museum Franken, Fürth in: Wielkomiejskie cmentarze żydowskie w Europie Środkowo-Wschodniej, ed. I. Gadowska, Wydawnictwo Hamal, Łódź 2016, p. 65.

7 H. Künzl, Jüdische Grabkunst von der Antike bis heute, Wissenschaftliche Buchgesellchaft, Darmstadt 1999, pp. 200-201.

8 M. Feinkind, Dzieje Żydów w Piotrkowie i okolicy od czasów najdawniejszych do chwili obecnej, Piotrków Trybunalski, publication financed by the author, 1930, p. 14. 
with "old customs", in a square by the synagogue. In 1809, for fear of an epidemic, the overcrowded cemetery was ordered to be closed under binding police regulations ${ }^{10}$, but on September 21st 1814, the Crown Property Administrative Chamber in Warsaw annulled that decision. According to a new agreement on perpetual lease concluded with the local Jewish community, 2 morgens and 164 lans of Magdeburg measurement were separated from unused land belonging to the Piotrków Crown Estate in order to enlarge the overcrowded Jewish cemetery by the synagogue ${ }^{11}$. However, according to Mojżesz [Moses] Feinkind, a new cemetery was already functioning near the town at that time ${ }^{12}$.

The order to bury the dead not earlier than three days after death and the necessity to have a doctor confirm a person's death led to genuine protests of Jews in many European countries. The introduction of the new law resulted from fears growing in the Enlightenment, concerning the burial of apparently dead people. The edict, although similar to orders given to Christians, was considered by Jews as repressive and inconsistent with their religious tradition. Polemics concerning the change in ritual continued throughout the 19th century and the order to observe the dead for several days was rarely respected, even in large cities. Nevertheless, it must be said that the new law contributed, to a certain extent, to the construction of pre-burial houses, which, in densely populated centres, could be used not only for washing and preparing a dead body, but also for storing it. The houses were particularly widespread in Germany where they were given a representative character, regardless of the users' religion ${ }^{13}$.

\section{Pre-burial houses in the Kingdom of Poland}

In the Kingdom of Poland with many small towns, the local Jewish community was so strongly attached to tradition that any attempts to implement a regulation contradicting its religious commandments were vigorously opposed. It is worth remembering, however, that the cause of this resistance was not only the conservative attitude of the Orthodox, but also purely pragmatic

9 Ibid.

10 K. Głowacki, Urbanistyka Piotrkowa Trybunalskiego, vol.1, Towarzystwo Przyjaciół Piotrkowa Trybunalskiego, Biuro Badań i Dokumentacji Zabytków w Piotrkowie, Kielecki Oddział Pracowni Konserwacji Zabytków, Piotrków - Kielce 1984, p. 63.

11 Ibid., p. 66.

12 M. Feinkind, Dzieje..., p. 30. According to Feinkind, the new cemetery was founded in 1792.

13 The author of the article in "Przyjaciel Ludu" wrote about pre-burial houses as follows: "A constant growth in their numbers in German countries shows why their erection is beneficial and convenient." Cf. K.R., O potrzebie domów przedpogrzebowych, "Przyjaciel Ludu: czyli tygodnik potrzebnych i pożytecznych wiadomości” 1840 , no. 6, p. 48. 
considerations. Taking into account the fact that pre-burial preparations until the end of the 19th century often took place at home, the corpse would have to remain there until the funeral according to the order, posing an immediate epidemiological threat. ${ }^{14}$ Dilemmas related to this issue are well described in an article published in "Izraelita" in 1877, whose author notes:

"This regulation is of great concern to the local Jewish population (...) It is a well-known fact that corpses of deceased Jews remain at home until burial. This circumstance, combined with the fact that Jewish families, belonging mostly to the poor class, are often housed in cramped one-room flats, makes it necessary to remove the corpse as soon as possible for the sake of the health of living persons (...). According to the regulations in force in our country, a corpse can be buried only after 48 hours from the moment of death. There are, however, quite a few cases in which police authorities allow for earlier removal. Currently, the abovementioned regulation does not allow for similar considerations, unless, first of all, a doctor's certificate is presented (...) such a certificate cannot always be obtained within a short time (...) and, most importantly, it will be connected with burdensome costs for the poor." 15

Following his considerations, Yisroel Leon Grosglik admits that the problem could be solved by the construction of a pre-burial house, yet it requires considerable funds which the communities (in this case the Warsaw one) do not have. He concludes by pointing out other reasons to the disadvantage of the regulations: "The existing practice of burying bodies of the deceased on the third and often the fourth day after death is detrimental to the economic wellbeing of the poorer classes of the population in general and of those who make their living by handicrafts and other manual labour in particular. (...) Jews suffer twice as much because their inactivity continues for seven or at least three days after the act of burial, as required by the ritual regulations." 16

The development of Jewish cemetery architecture, which began in the 18th century with Enlightenment slogans of emancipation and secular assimilation, continued throughout the 19th century in Central and Eastern Europe. Numerous municipal Jewish cemeteries were removed (at least partially) from the guardianship of burial fraternities and communal boards, and were given the supervision of non-religious governmental institutions. This was the

14 The problem concerned not only Jews, but also Christians, as Kazimierz Chechłowski, among others, wrote in 1901. See: K. Chechłowski, O potrzebie u nas domów przedpogrzebowych, "Zdrowie" 1901 , no. 1, pp. 5 -6.

15 I. L. Grosglik, W sprawie chowania zwłok, "Izraelita" 1877, no. 2, p. 15.

16 Ibid., p. 16. 
case with French or German necropolises. The metropolitan cemetery became a representative place thanks to a new approach to spatial planning, departure from traditional forms of gravestones, a change in funeral ceremonies (which became similar to Christian ones) and modern cemetery buildings. Despite radical changes influencing their external appearance, the non-Orthodox cemeteries of the late 19th century met religious requirements. The process of transformation is well visible when cemetery architecture throughout Central Europe is examined, where its intensity, as mentioned above, remained closely related to the assimilation level of specific communities and the strength of influence of non-Jewish environment.

\section{The pre-burial house in Lódź founded by Herman and Mina Konstadt}

The first funerals in the new Jewish cemetery in Łódź were organised at the end of 1891 on the so-called Stare Pole [Old Site] comprising two plots located on land donated to the community by Yisroel K. Poznański and situated in the western part of the existing cemetery. The way that the funeral procession had to take to get from the city to the burial place led through fields, far away from the buildings, which gave the participants of the ceremony the desired discretion. However, there was a real danger that a dead body, washed and prepared in the house of mourning, would become contaminated during the long journey. This was very likely, given that at the end of the 19th century, regardless of the legislation in force, corpses were usually transported on a stretcher, covered only with a cloth. Another danger associated with the distance and transport of the dead was the fear of not exceeding three hours, the maximum time that could separate the ritual of tahara from burial. Therefore, from the very first moment that the new necropolis started functioning, there was an important problem that required quick action, i.e. the construction of a multi-purpose pre-burial house which would include rooms for the ritual washing of a dead body, as well as other rooms for displaying corpses, liturgy, recitation of the eulogy (hesped) and psalms. ${ }^{17}$ In the first years after the cemetery's opening, the pre-burial house was a makeshift building, destroyed by fire in August 1896. This sad incident was described in "Izraelita": "Last week, in one of the sheds

17 Regarding the pre-burial house at the Jewish cemetery in Łódź, see also: G. Ignatowski, Poczatki i dzieje nowego cmentarza żydowskiego w Łodzi”, Biuletyn Żydowskiego Instytutu Historycznego w Polsce” 1987, no. 3-4 pp. 59 - 69; D. and L. Muszyńscy, Cmentarz żydowski w Łodzi, Oficyna Bibliofilów, Łódź 1995; I. Kersz, Szkice z dziejów Gminy Żydowskiej oraz cmentarza w Łodzi, Oficyna Bibliofilów, Łódź 1999; I. Gadowska, B. Walczak, Zabudowa cmentarza w: Cmentarz żydowski w Łodzi, "Monumenta et Memoria” ed. L. Hońdo, Wydawnictwo Hamal, Łódź 2016, no. 1, pp. 53-58. 
situated next to the new cemetery, a fire broke out for some unknown reason. It destroyed two neighbouring sheds filled with freshly transported hay [...] In one of the sheds there were two bodies of the deceased which were barely removed. The beds of the former cholera hospital for Jews, which had been placed there, were also burnt." 18

In 1896, Mina Konstadt, represented by Jacob Hirszberg, Josef Fraenkel and Edmund Krakowski, pledged to finance the construction of a pre-burial house which would meet technical, sanitary and representative requirements. The donated sum of 18,000 silver roubles was at the same time her payment for a family tomb comprising eight burial plots in the left D section (nos. 1, 2, 3, 4, 26, 27, 28 and 29). Mina Konstadt owned a huge fortune left by her husband Herman, a well-known industrialist and philanthropist, who died in 1895. According to his will, the inheritance was to be capitalised and the interest from it was to be used for family and charitable purposes. According to a letter addressed to the Board of the Jewish Community in Łódź, one of the conditions of financing the construction of the pre-burial house was placing a foundation plaque with the names of the donors on the façade and in the interior. ${ }^{19}$ The cornerstone of the pre-burial house was laid in early September. The design was prepared by Adolf Zeligson and submitted to the founder by the community board. The architect planned to erect a modern, comfortable building that could contain isolated dwellings for the cemetery staff. The ceremonial rooms were to be equipped with stone and marble floors and tables, making it easy to maintain cleanliness. ${ }^{20}$ Eventually, the idea of placing ritual and residential rooms under one roof was abandoned. In 1896, at the same time as works on the pre-burial house began, efforts were made to build a separate building for the cemetery staff. The employees who could not live nearby were forced to cover the distance between the town and the necropolis (no less than 16 versts) several times a day. They complained about the loss of time and health, especially in spring, autumn and winter, when they did not leave their workplace in unfavourable weather conditions and remained without a hot meal for several hours. A growing number of funerals - 1189 in 1893, 1910 in 1894 (cholera outbreak), 1284 in 1895 and 1381 by November 1896 - made it necessary for the whole cemetery staff to be on permanent duty. According to religious commandments, a prayer quorum of ten men should be present at a funeral, which, with six ceremonies a day, meant that none of the employed men could leave their workplace. In view of this, it was requested that housing be provided for

18 N.K., Łódź w sierpniu, "Izraelita” 1896, no. 33, pp. 280-281.

19 Archiwum Państwowe w Łodzi, Łódzka Gmina Wyznaniowa Żydowska [State Archive in Łódź, Jewish Community in Łódź], No. 5, pp. 201-203.

20 N.K., Łódź, we wrześniu, "Izraelita” 1896, no. 37, p. 318. 
the caretaker, the gardener, the guard and their families. Agreeing with the arguments of cemetery employees, the members of the Synagogue Board decided that there was no space to build a house within the boundaries of the existing necropolis and even if there was, it was impossible for hygienic reasons. Therefore, efforts were made to purchase additional land, i.e. several adjacent plots. The cost of the undertaking, including purchase of the land and erection of a building with flats for 15 families, was estimated at 10,000 roubles. The sum was to be collected thanks to voluntary donations from the citizens of Łódź. ${ }^{21}$ On 11 November 1896, a request for permission to purchase additional land was submitted to the city mayor. ${ }^{22}$

The works on the pre-burial house, directed by Zeligson, lasted for a little over a year. ${ }^{23}$ At the same time, the architect was involved in the revival and reconstruction (in the Moorish style) of the community synagogue on Wolborska Street. ${ }^{24}$

The newly built pre-burial house was officially opened on 29th October 1897 at 9 a.m. The ceremony was preceded by a memorial service organized at the shelter for the poor, elderly and crippled on 54 Średnia Street (54 Pomorska Street) and followed by the unveiling of Herman Konstadt's monument at the cemetery. ${ }^{25}$ The ceremony was attended by his family, friends and numerous citizens, Rabbi Eljahu Chaim Majzel, Dr Yisroel Jelski, as well as the cantor and choirs from the synagogue. The building was consecrated a few months later, on 25th April 1898. ${ }^{26}$ The correspondent of "Izraelita" noted: "this new vestibule of the Sanctuary of the Dead corresponds in every detail to its purpose, since the builder Zeligson took into consideration everything that the hygiene of this kind of a building requires. Thanks to the generous donation of Mrs Konstadt, the unhygienic and unpleasant shed has been transformed into a magnificent and aesthetically pleasing pre-burial house, a place of tears, groans of despair and pleas for eternal peace for those leaving this earthly plane." 27

21 Archiwum..., No. 5, pp. 144-148.

22 Ibid., p. 140. A sketch showing the outline of the employee building foundations was included on the façade design of the pre-burial house. This may indicate an earlier intention to organise social facilities for the cemetery staff, yet the schematic representation does not exclude the possibility that the plan was drawn later on the finished design. Cf. photo of the pre-burial house façade design in the collection of the Provincial Office of Monument Preservation in Łódź (files of Bronisław Podgarbi.)

23 Unfortunately, it was not possible to establish which construction companies were employed to perform the works at the cemetery.

24 A. Starkman, $Z$ Łodzi, "Izraelita" 1895 , no. 1, p. 6; regarding the history of construction and revival of the synagogue on Wolborska Street in Lódź, see: K. Stefański, Architektura sakralna Łodzi w okresie przemystowego rozwoju miasta 1820-1914, Łódź 1995, pp. 47-52; J. Walicki, Synagogi i domy modlitwy w Łodzi, Ibidem, Łódź 2000, pp. 15-35.

25 Archiwum ..., No. 5, p. 166.

26 Ibid., p. 149, 150.

27 N.K., Łódź w październiku, "Izraelita” 1897, no. 43, p. 19. 
The day before the event commemorating Herman Konstadt, on Thursday, October 28th, 1897, during Jacob Sachs's monument blessing ceremony, the son of the deceased, Isidor, handed over the keys to the house for the cemetery staff to Yisroel Poznański. ${ }^{28}$

The pre-burial house was a multifunctional building which combined services related to preparation of the deceased for funerals with administrative activities. It was one of the utility facilities of the necropolis, but it was notably erected mainly as a building of key importance. ${ }^{29}$ Its location indicates the consistent implementation of a concept according to which the core of the cemetery was a representative avenue with a tahara house on the main axis. Zeligson took into account the aesthetic aspect of the whole, as well as, more importantly, the issue of communication facilities for processions going from the main hall towards the burial part of the necropolis.

\section{Architecture}

The edifice was made of burnt clay brick on lime mortar, on foundations $1 \mathrm{~m}$ below the topsoil layer. It was a one-storey building with a partial basement from the eastern side, on a rectangular plan. The dominant feature of the structure is a clearly visible central avant-corps with wings adjoining from the north and south with small avant-corpses along the outer axes. A tripartite layout of the longer elevations corresponds to the interior layout. The central part of the complex is occupied by a high ceremonial hall covered with a gable roof of wooden construction, framed on both sides by lower rooms used for preparation of the deceased and for mourners. A similar design can be found in other

28 Ibid.; Archiwum..., No. 5, p. 169. Archival documents contain a letter from 1898, which indicates that the efforts made two years before to purchase additional plots of land for the house construction resulted in a failure. The Synagogue Supervisions, supplementing their report of 11th November 1896, explained that the request for the purchase of three additional plots of land for the Jewish Cemetery was caused not only by the need to build houses for the people who worked at the cemetery, but also by the lack of rooms for storing equipment and, above all, by the necessity to find a proper place for the city residents who accompanied the deceased in funeral processions and carriages arriving at the cemetery, which sometimes reached the number of three hundred. According to Grzegorz Ignatowski, the house for cemetery staff and the remaining cemetery buildings were erected before 1914 . In the light of press reports and later documents, this happened earlier. Cf. Archiwum..., No. 5, pp. 132-133; G. Ignatowski, Poczatki i dzieje "Nowego Cmentarza" Żydowskiego w Łodzi, "Biuletyn Żydowskiego Instytutu Historycznego w Polsce” 1987, no. 3-4, p. 67.

29 In addition to the pre-burial house, the utility section of the cemetery also included a synagogue, a mikveh, a water tower (a building equipped with a motor and an iron boiler), a house with nine flats, a wooden shed and a hut for Sukkot. In the area that was part of the necropolis, apart from a house with five apartments, there was a barn, a well, a toilet and an orangery. 
buildings of this type from the second half of the 19th and early 20th century. A comparable model was used e.g. in Bielsko (designed by Carl Korn, 1885) or Gliwice (designed by Max Fleischer, 1903). The façade with three avantcorpses, housing the ceremonial hall in the central one, also appeared in the winning design of a pre-burial house for the new Jewish cemetery in Podgórze near Cracow, prepared by Adolf Siódmak (1922) and implemented ten years later. ${ }^{30}$ The abovementioned buildings are examples of large-volume structures, containing several rooms, adapted for larger gatherings. On the other hand, the functionality and utilitarian value of the pre-burial houses in Łomża (1892) and Tarnowskie Góry (1894) was reduced. In the context of Łódź, they should be remembered not only due to certain similarities in the design of selected elements of the façade, but also taking into account the time of their construction and, in the case of the former, its location in the Russian sector.

The pre-burial house in Łódź, completed in 1897, was considered to be the largest and the most modern building of this type in the Kingdom of Poland at the time. Its scale and representative character clearly confirmed the growing importance of the Jewish community in Łódź, which then was the second most densely populated city only after Warsaw. ${ }^{31}$ A short article about Herman Konstadt added to "Neue Lodzer Zeitung" mentioned that the foundation was of "aesthetic and ethical, but also hygienic" importance. ${ }^{32}$ The need to guarantee appropriate sanitary conditions during the preparation of a dead body and burial itself became particularly significant in view of the growing population of Łódź, which, as far as Jews are concerned, increased from about 271 people in 1820 to 14,400 in 1880 and 31,600 in the period preceding the establishment of the new cemetery. ${ }^{33}$ The ceremonial hall founded by Mina Konstadt met most of the postulates formulated in 1846 by the Administrative Council of the Kingdom of Poland. According to the regulations established by the Council, pre-burial houses were to be erected in open spaces. "In more considerable cities, the best option is to choose a place at the edge of the city, or on some spacious square, surrounded by gardens, not enclosed by high buildings and not densely populated." 34 The legislator distinguished three pre-burial house degrees, which depended on the size and variety of functions. First-degree

30 B. Zbroja, Miasto umartych. Architektura publiczna Żydowskiej Gminy Wyznaniowej w Krakowie w latach 1868-1939, WAM, Kraków 2005, p. 93, 98.

31 Rocznik statystyczny Królestwa Polskiego. Rok 1914, ed. W. Grabski, Gebethner and Wolff, Warszawa 1915, pp. 34-35.

32 Paul P., Hermann Konstadt. Ein Gedenkblatt zu seinen 7-jährigen Todestage, "Illustrierte Sonntags Beilage: Handels und Industrieblatt. Neue Lodzer Zeitung" 1902, no. 4, p. 31.

33 F. Friedman, Ludność żydowska Łodzi do r. 1863 w świetle liczb, "Kwartalnik Statystyczny" 1933, vol. 10, no. 4, p. 469; J. Janczak, Ludność Łodzi przemystowej 1820/-1914, Uniwersytet Łódzki, Łódź 1982.

34 Policya Lekarska. O grzebaniu ciat zmartych, Drukarnia Stanisława Strąbskiego, Warszawa 1846, p. 67. 
houses had one or more rooms for depositing bodies, a room for the guard, a post-mortem room, a room "for providing rescue in case of apparent death", a flat for caretakers, a kitchen and a "storeroom for funeral accessories." Second-degree houses had two rooms for the dead, a guarding room serving as a caretaker's flat, a room for rescuing people in emergencies, a kitchen and a storeroom. Third-degree houses had one room for the deceased, another for a guard, a kitchenette, a storeroom and a hallway. ${ }^{35}$

The pre-burial house in the Łódź cemetery can be classified as a first-degree one, bearing in mind, however, the specificity of Jewish burial rituals and the resulting differences in defining the function of the facility. The abovementioned regulations and categorisation were general: they applied to facilities used by different religious groups. In the case of Jewish funerals, it was recommended that they be organised as soon as possible - on the day after death. The ceremony was sometimes postponed due to insufficient time to prepare a dignified ceremony or because of religious holidays. The legal regulation requiring that burials should take place 48 hours after death was not observed by Jews. As a consequence, Jewish pre-burial houses were not intended to provide longer storage for dead bodies. The arrangement of "forensic investigation" rooms recommended by the Policyja Lekarska [Medical Police] was inconsistent with Jewish law which forbade mutilation of the dead. Therefore, autopsy rooms were rarely found in Jewish pre-burial houses in present-day Polish territory. Cracow was an exception. The plans of a cemetery building on Miodowa Street provided for a separate room for examining dead bodies. ${ }^{36}$ In the Kingdom of Poland, probably due to the strong position of Orthodox circles, there was no such case. Moreover, none of the researched buildings had rooms intended to provide assistance to people who were previously declared dead. The fear of being buried alive was so great that the regulations in question devoted three chapters to this problem, describing the procedures to be followed in the case of a sudden "awakening" of an apparently dead person and ones to be used to categorically confirm death. ${ }^{37}$ A separate section dealt with the tools needed "for rescue in emergency cases and for reviving in case of an apparent death". ${ }^{38}$

35 Ibid., p. 69.

36 Cf. L. Hońdo, Dom przedpogrzebowy przy żydowskim Nowym Cmentarzu w Krakowie, Universitas, Kraków 2011, pp. 83-86.

37 Policya Lekarska, pp. 30-63.

38 The regulations list the following devices: a pump and patches for breast compression to restore breathing; baths, bed warmers and quilts to warm the body; bloodletting tools, bands, cloth pads and a device for placing cups to draw blood; rubbing brushes, camphor, wool rubs, Hoffmann's pain-relieving drops, a syringe, tobacco, acupuncture needles, galvanic cells and an aromatic mixture of lavender, sage and benzoin gum resin to restore the nervous system function; a wooden rod and a rod with a spring to make/hold jaws open, as well as: scissors, a flannel sheet, a flannel cap, a spoon, a mug, matches, tinder and oil for the tools. For more information on the topic, see: Policya Lekarska, pp. 73-77. 
The inventory of the pre-burial house in Lódź does not mention any similar tools. They were not used, probably due to the danger of possible desecration of a dead body.

So, what did the interiors look like and how were they furnished? According to the 1917 floor plan, the central part of the building was occupied by a ceremonial hall adjoined on both sides by rooms for various purposes. These were rooms for the public, symmetrically located at the front, as well as rooms for washing the dead bodies of men (south) and women (north) ${ }^{39}$ at the rear with adjacent mortuaries. In the north wing, there was a room for ladies, a sewing room and a guard's room, while in the south wing - an office and a synagogue. ${ }^{40}$

The spatial layout of the pre-burial house in Łódź is well-considered and functional. The system of passages between individual rooms ensured good internal communication, which was important for improving the work of the cemetery staff. Spacious rooms for guests were comfortable and their symmetrical arrangement separating men and women indicated respect for tradition. The interior design was characterised by simplicity expressed through limited decoration and modest furnishings. The most representative part was the prayer room built on a rectangular plan, illuminated by four stained-glass windows on the east wall and a monumental window on the western side. The room is spanned with a wooden ceiling and a gable roof reinforced with four arched openwork trusses. The floor was paved with terrazzo with a chequerboard pattern. The side walls were painted with blue distemper and had an ornamental

39 According to the building documentation and expert opinions on its state of preservation issued by the Provincial Office of Monument Preservation in Lódź, rooms for men were located in the north wing of the pre-burial house and those for women in the south wing. Information on the reversed location of the rooms provided by me is based on a plan made for the Municipal Estimating Committee in 1917, i.e. at the time when the building functioned as intended. Cf. Wojewódzki Urząd Ochrony Zabytków w Łodzi [Provincial Office of Monument Preservation in Łódź], Register cards of architectural and construction monuments, Pre-burial House, prepared by A. Lewkowska, W. Walczak, 1996; Wojewódzki Urząd Ochrony Zabytków w Łodzi [Provincial Office of Monument Preservation in Łódź] No. 406/1, Technical documentation, pre-burial house, prepared by Z. Heyda, 1982, p. 2; Ibid., No. 407/7, Technical documentation, pre-burial house, prepared by Z. Heyda, 1982, p. 1, 3.

40 I. Gadowska, B. Walczak, Zabudowa cmentarza, pp. 54 -55. The purpose of the last room raises some doubts. At the time when the drawing was made, a synagogue functioned next to the cemetery in a separate building, so there was no need to arrange a special room for religious purposes. Perhaps it was intended to serve the Cohanim, who, due to a religious ban, could not stay close to a corpse. This hypothesis is supported by the fact that this room is almost completely isolated from the remaining ones, with only one entrance leading through the office. The argument refuting this assumption is the immediate vicinity of the mortuary. Both rooms are covered with one roof and separated only with a wall. It is possible that the room served as a synagogue temporarily, due to the destruction of the cemetery synagogue during the First World War. 
pattern applied using a roller. Their lower parts, up to the height of $1.5 \mathrm{~m}$, were covered with oil paint, with the motif of two-coloured diamonds and a horizontal border filled with plaiting. The pilasters that the beams were attached to were decorated with red and white horizontal stripes in the neo-Moorish style. In the composition of the eastern wall, vertical accents determined by panels and tall window openings were balanced by horizontal stripes of painted decoration and moulded stringcourse dividing the surface into lower and upper zones. At the top, there were four round-headed windows with a central glazed panel including a rosette and the Star of David.

\section{The question of style}

Like many Jewish architects designing public buildings in the 19th and at the turn of the 20th century, Zeligson had to make decisions regarding not only the form and interiors of the building, but also the details that gave the whole a specific character. The western façade of the pre-burial house, with its large arched window, is reminiscent of market halls and railway stations. Bare red brick used in the construction provided reference to the industrial architecture of the factory town. However, it is mainly the neo-Moorish elements visible on the outside and in the main hall that give the building its stylistic specificity. In an article on Orientalism in synagogue architecture, Ivan Davidson Kalmar distinguished several features due to which the style ${ }^{41}$ may be classified as Moorish, e.g. stone parapets with ornamental crimping inspired by Islamic art, round-headed windows and doors, domes reminiscent of the Middle or Far East, turrets resembling minarets, horizontal stripes in two alternating colours decorating facade planes, Alhambra-inspired pillars with floral capitals and polychrome horseshoe arches in the interiors. ${ }^{42}$ At the same time Kalmar noted: "The Moorish style could never be pure. No architect ever aimed to recreate an actual Oriental palace or mosque (let alone one of the famous "Oriental" synagogues such as those of medieval Spain) on Western soil. The ground plan, structural engineering and important stylistic elements always reflected contemporary Western tastes and practices. What was Islamic was mainly deco-

41 Orientalism as a style became widespread in the 1830s, which was associated with publications on the Alhambra of Granada, inventoried and described in detail at the time. Apart from Moorish architecture, other important references include the Temple of Solomon, especially its reconstruction, published in 1889. Leitmotifs taken from the buildings of ancient Babylon or the architecture of the Ottoman Empire were also readily used. Thus, Jewish construction fitted into the general trend of historicism and eclecticism in late 19th-century architecture.

42 I. Davidson-Kalmar, Moorish Style: Orientalism, the Jews, and Synagogue Architecture, "Jewish Social Studies" 2001, vol. 7, no. 3, p. 73. 
rative. The only structural element adapted from the "Orient" were perhaps slender pillars with floral and plant capitals. And these, too, were often made of iron, using the latest Western methods of construction." 43

In the pre-burial house in the Jewish cemetery in Łódź, Moorish decoration was moderate though visible. On the outside, there were cast-iron columns and a decorative frame of the main entrance (on the western side), as well as windows and door panels with oriental arches, while inside polychrome walls with the motif of the sky and two-coloured stripes (undistinguishable today) were applied. Why did Zeligson use the well-known repertoire of neo-Moorish details? It is not clear nowadays. As a designer, he was undoubtedly responsible for making decisions, although the construction committee and the founder, Mina Konstadt, also had some influence on the shape and decoration of the building. At the beginning of the 19th century, Western European architects debated on the relationship between style and function of a building. Many of them were convinced that ancient Greek and Roman architecture, and the architecture of the Renaissance which drew on this tradition could provide a model for urban construction. The Romanesque and Gothic styles (associated with Christianity) were supposed to be more appropriate for religious buildings, with Gothic being perceived as closer to the Catholic church. Among synagogues built in the 19th century, we can find neo-Classical, neo-Gothic and neo-Romanesque buildings, but construction officials, architects and even representatives of the Jewish circles believed that styles associated with the Christian religion were not appropriate for Jewish ritual buildings. At that time, Jews were perceived (also by themselves) as an "Oriental people" or a "Semitic race", so it is not surprising that the appropriate style for Jewish architecture (i.e. primarily religious buildings) was sought in the Eastern tradition - the temples of the ancient Egypt, the Temple in Jerusalem and the architecture of Islam as rich repositories of diverse designs. The Moorish (or neo-Moorish) style, which originated in England, is a historical trend. It was popularised by Western European architects inspired by Ottoman buildings and the architecture of Moorish Andalusia. From the 1840s to 1914, it was used by Jewish and non-Jewish architects, primarily in synagogue buildings. As Davidson Kalmar noted, Jews themselves "hoped to make Orientalist idealizations of themselves prevail over the Orientalist vituperations. Rather than rejecting the East-West dichotomy and the rhetoric of race, they bought into it. They hoped that they could convince the public of the nobility of their Oriental blood - and sometimes they did. The Moorish-style synagogue was an expression of their quest." ${ }^{44}$

43 Ibid. p. 72.

44 Ibid., p. 71. Jews, representing similar beliefs, were of the opinion that the fashion for Orientalism, which spread through travel, literature and art, expressed genuine admiration for the East. According to Edward Said, the essence of Orientalism was to point out the Other as completely subordinated and ultimately rejected. 
Of course, the discussion on the use of the Moorish or, more broadly, Oriental style in synagogues applies to other Jewish public buildings only to some extent. The new Jewish cemetery in Łódź was originally located outside the city borders. The pre-burial house did not have to be as representative as buildings located closer to the centre. In Zeligson's design, Moorish detail, on the one hand, anticipates modernity, while on the other one it expresses conscious effort made by the architect and his principals to include their own (Jewish) tradition in the visual context of urban development defined by the architecture of the (non-Jewish) majority.

\section{Other interiors - comparisons}

Although the pre-burial house in Łódź was erected at a time when the city was at the peak of its development and the Jewish community was simultaneously carrying out several prestigious investments, the orientalising decoration of the interior seems modest in comparison with the halls of other representative cemetery ceremonial buildings erected in the second half of the 19th and the first decades of the 20th century. The most interesting ones include the main hall of the pre-burial house in Bielsko ${ }^{45}$ with a two-coloured terracotta floor decorated using a border with a plaiting motif and a tray ceiling featuring a colourful polychrome work with geometric and floral patterns, ${ }^{46}$ the interiors of the pre-burial house in Katowice (1876) covered with paintings presenting illusory columns and images of craftsmen at work, the tahara room in Gliwice with a neo-Gothic groined rib vault decorated in 1905 with a polychrome work depicting a starry sky and floral ornaments. ${ }^{47}$ The abovementioned buildings were erected for Jewish communities in Upper Silesian towns where a significant percentage of citizens underwent assimilation and German acculturation. There were three other pre-burial houses built between 1900 and 1914 in the German Empire, characterised by different artistic designs of the ceremonial hall, whose interiors are worth describing as examples of aesthetic transformation and assimilation of current artistic trends. These are: the no longer existing purification house in Wroclaw (the new cemetery) and pre-burial houses in Munich (the new cemetery), Worms (the new cemetery) and Olsztyn.

45 Currently Bielsko-Biała, a city in the south of Poland. In the 19th century it was incorporated into Galicia and became part of the Austrian Empire.

46 J. Proszyk, Cmentarz żydowski w Bielsku-Biatej, Urząd Miejski w Bielsku-Białej, Wydział Kultury i Sztuki, Bielsko-Biała 2002, pp. 101-110. The walls of the main hall of the pre-burial house in Bielsko originally featured some paintings that were covered with white paint in the post-war period.

47 More about the pre-burial house in Gliwice: M. Żmudzińska-Nowak, Dom przedpogrzebowy na nowym cmentarzu żydowskim - gliwickie dzieto Maxa Fleischera na tle innych jego realizacji w Europie Środkowej in: Żydzi Gliwiccy, ed. B. Kubit, Muzeum w Gliwicach, Gliwice 2006. 
Unlike in Łódź, the Wroclaw hall was located in a separate building, a chapel erected on the central plan connected with a mortuary using an arched gallery. Designed in the neo-Romanesque style in 1900-1902 by Richard and Paul Ehrlich, it could accommodate 400 people (100 seated and 300 standing) and a choir in the women's section. The room, spanned with a 12.3 metre stellar vault, opened out onto the cemetery from three sides. ${ }^{48}$ The interior decoration was the work of the well-known Wrocław painter, Hans Rumsch, the author of the painting decoration in the School of Building Crafts and main decorator of the Wrocław Exhibition of Crafts in 1904. The austere simplicity of the brick walls, only partially covered with plaster, was enriched by an ornamental frieze with a motif of braided tendrils and flowers. Above the doors leading to vestibules, in arched niches, there were painted images of leafy branches. The vault ribs and arches of the upper storey were accentuated by two-coloured stripes. The webs between the ribs were filled with polychrome works. The floor of the chapel was covered with stained xylopal stone. ${ }^{49}$

The new Jewish cemetery in Munich was built between 1904 and 1908. The necropolis, together with all the utility and administrative facilities, designed by Hans Grässel (1860 - 1939), a renowned Munich architect and author of other municipal cemetery designs, was opened on 18th May $1908 .{ }^{50}$ The complex of cemetery buildings was dominated by a square-shaped chapel covered with a hipped roof, with a small apse in the east and an arcaded portico with a triangular pediment in the west. Its style can be described as modernised and strongly simplified neo-Baroque referring to the architecture of Central and Eastern Europe. The body, characterised by simplicity and reduction of decorative details, shows analogies with another Grässel's building from the same period, namely the chapel in the Waldfriedhof cemetery in Munich. The interiors of both buildings also share some similarities resulting from a reinterpretation of Renaissance patterns. The $14 \times 14$-metre Jewish prayer room is covered with a richly decorated mirror vault, below which twelve oval windows are placed in lunettes, three on each wall. The vault is decorated with stucco details including relief rosettes, corbels, cartouches, vases, garlands, etc. The interior design features clear articulation of the walls with the use of pilasters having Corinthian capitals, between which there are empty rectangular fields. Above them there is trabeation with a frieze inscribed with sentences referring

48 R. and P. Ehrlich, Israelitische Friedhofsanlage für Breslau, "Zentralblatt der Bauverwaltung" 1903, no. 27, pp. 168-169.

49 Xylopal: a material used as floor lining instead of flooring. Made of wood meal and a binder, it is coloured mass imitating wood, insensitive to moisture. Sanded, coated with paraffin or linseed oil and then terraced, it resembled a parquet floor.

50 München, 18 Mai, "Der Israelit" 1908 of 28.05 as cited in: http://www.alemannia-judaica.de/ muenchen_friedhof.htm (accessed: 1.01.2018) 
to death, written in German and Hebrew, e.g. VON STAUB BIST DU. ZU STAUB WIRST DU. ("For you were made from dust, and to dust you will return"), a fragment of Psalm 23.4 and others. Across the entrance, there is an apse with a place for the rabbi, enclosed by two seven-branched bronze candelabra and marble benches upright to the walls. Four hanging chandeliers with octagonal rings featuring rich oriental decorations are an important element enriching the decor. ${ }^{51}$

In the mourning hall in the new Jewish cemetery in Worms, which was opened in November 1911, the late Art Nouveau body corresponds to the subtle ornamentation of the interior in the spirit of the Vienna Workshop. When the designer of the necropolis, Georg Metzler (1868-1948), took up the post of the city architect in Worms in 1899, Ernst Ludwig, Grand Duke of Hesse, founded an artistic colony in nearby Darmstadt, making the city one of the most important centres of German Art Nouveau. The key figures in Darmstadt were Peter Behrens (1868-1940) and the Austrian Josef Maria Olbrich (1867-1908). The latter significantly influenced the implementation of Viennese patterns in the architecture and craftsmanship of the city, and smaller centres within its sphere of influence. The pre-burial house in Worms combines several functions within one building. Its main part consists of a more than 9-metre-high ceremonial hall with a wooden tray ceiling, preceded by one large vestibule with two smaller ones on the sides. Behind it, along the corridor leading to the cemetery exit, there are symmetrically arranged mortuaries for men and women and other auxiliary rooms. ${ }^{52} \mathrm{~A}$ characteristic feature of the spacious interior are limestone columns with straight shafts and capitals with relief gilt details, which carry decorative entablature. An arched niche above the portal is filled with a painting depicting a stylised plant strand with sapphire flowers, symbolising the tree of life. The walls of the ceremonial hall were divided into rectangular panels, alternately plain or covered with abstract, geometric-spiral ornaments.

Jewish pre-burial houses built in the following decades of the 20th century were characterised by a striving to give the prayer room (located inside or in a separate building) a more representative character. Its décor was intended to evoke noble sentiments while serving contemplation and inner tranquillity. At the same time, as the ceremonial hall gained the status of the most important room in the whole cemetery complex, rooms used for washing dead bodies lost their significance, despite retaining their original ritual function. Thus, the purification house turned into a house of the last farewell. In the Middle Ages and modern

51 R. A. Linhof, Die Kultur der Münchener Friedhofs-Anlagen Hans Grässels. "Wasmuths Monatshefte für Baukunst” 1918, nos 6-7, pp. 215 -216.

52 G. Metzler, Die neue Friedhofsanlage in: Zur Geschichte der Wormser jüdischen Gemeinde, ihrer Friedhofe und ihres Begräbniswesens, Kräutersche Buchhandlung, Worms 1911, p. 50. 
times, the eulogy was given directly at the cemetery. That custom also survived in later centuries, especially in smaller centres. In large cities, the ceremony was moved to the interior and gained an architectural and artistic setting.

\section{Summary}

The prayer rooms described here are characterised by varied decoration corresponding to contemporary trends, the taste of the founders and the expectations of the dominant group in the local Jewish community. Against this background, the interior of the prayer room in the pre-burial house in Łódź, which for a short time was considered the most modern building of its kind in Central and Eastern Europe, appears to be a functional space with a design that lags behind Western European architecture. However, it should be remembered that the neo-Moorish style, which was used there, was still very popular at the turn of the 20th century. It was explained by the desire to emphasise the eastern roots of Diaspora Jews. For them, as Amalia Reisenthel rightly observed, "the desire to demonstrate their own identity in relation to the past, without threatening social and political integration, was a central dialectical tension in the historical discourse". ${ }^{53}$

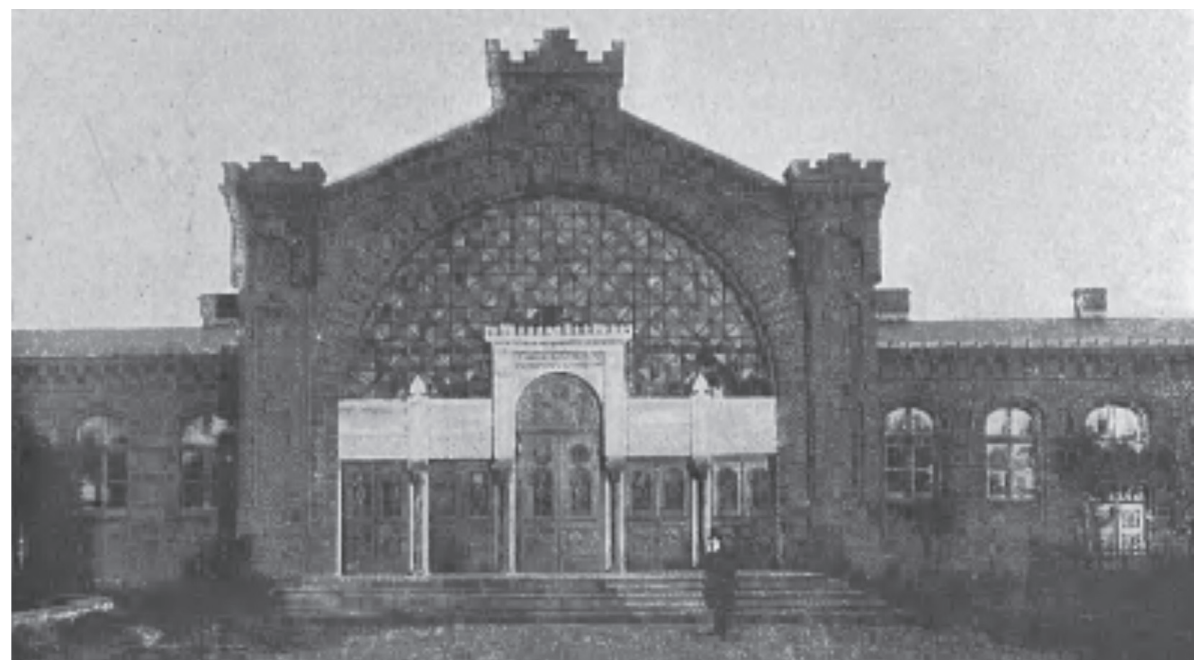

1. The pre-burial house at the new Jewish cemetery in Łódź. Architect: Adolf Zeligson, 1897. "Illustrierte Sonntags Beilage: Handels und Industrieblatt. Neue Lodzer Zeitung", 1902, no. 4, p. 29.

53 A. Reisenthel, Orientalismus als Mittel zur Identitätsfindung. Sepulkralarchitektur auf dem Jüdischen Friedhof Breslau, Lit Verlag, Berlin 2015, p. 16. 


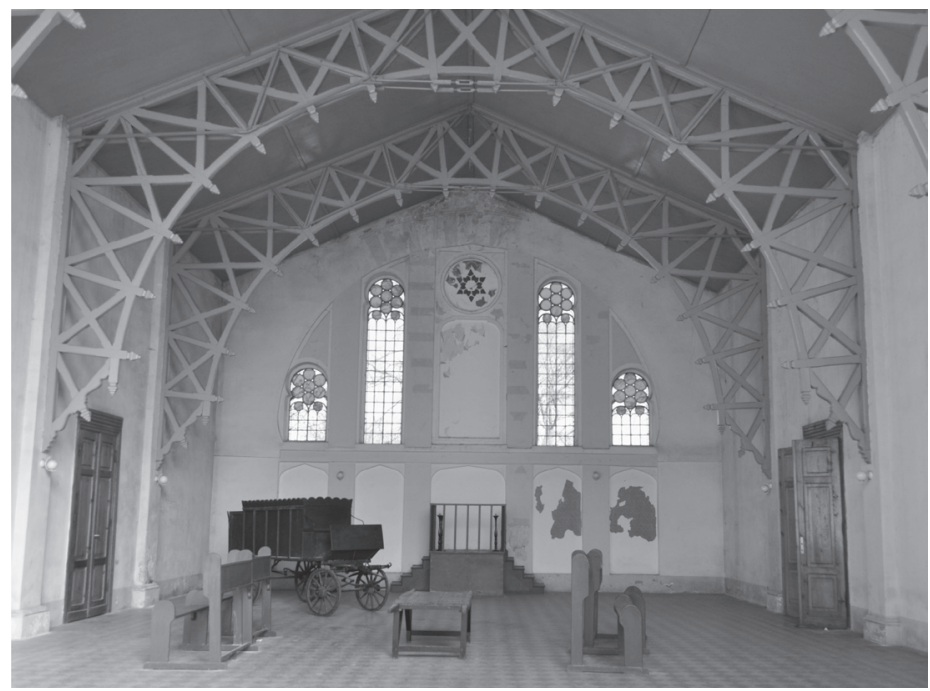

2. The interior of the main hall of the pre-burial house at the new Jewish cemetery in Łódź. Architect: Adolf Zeligson, 1897. Photograph by I. Gadowska, 2020.

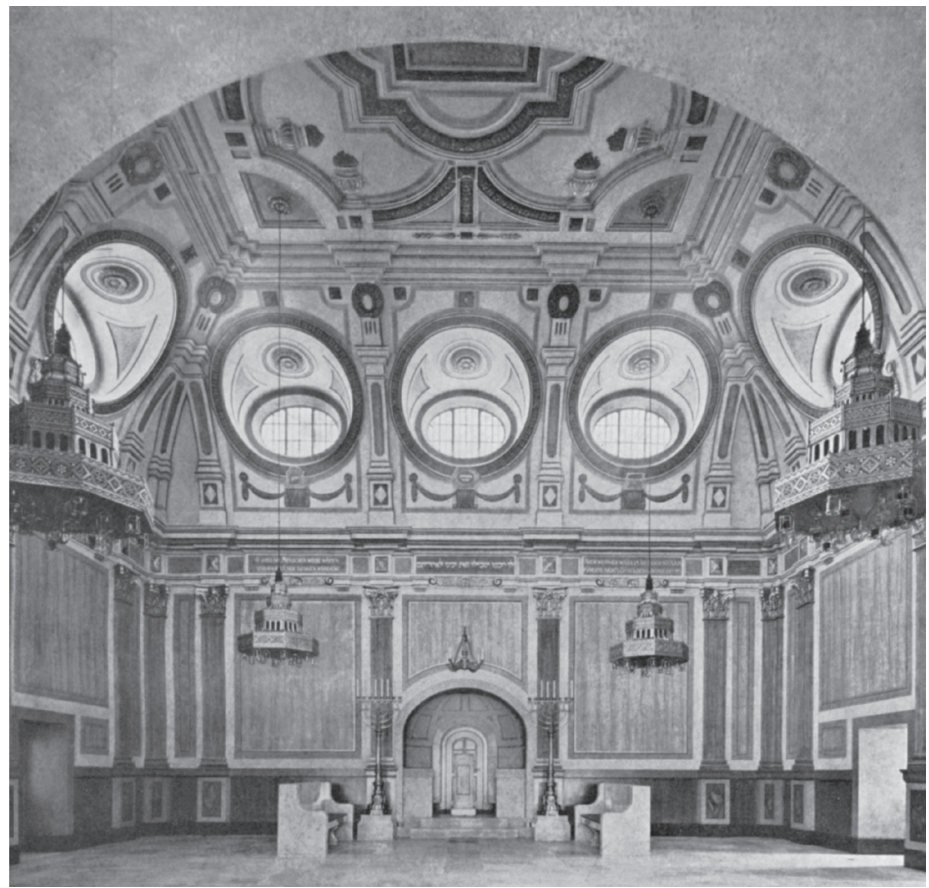

3. The interior of the main hall (chapel) of the pre-burial house at the Jewish cemetery in Wrocław (Lotnicza street). Architects: Richard and Paul Ehrlich, 1901-1902. "Zentralblatt der Bauverwaltung" 1903, no. 27 p. 169. 


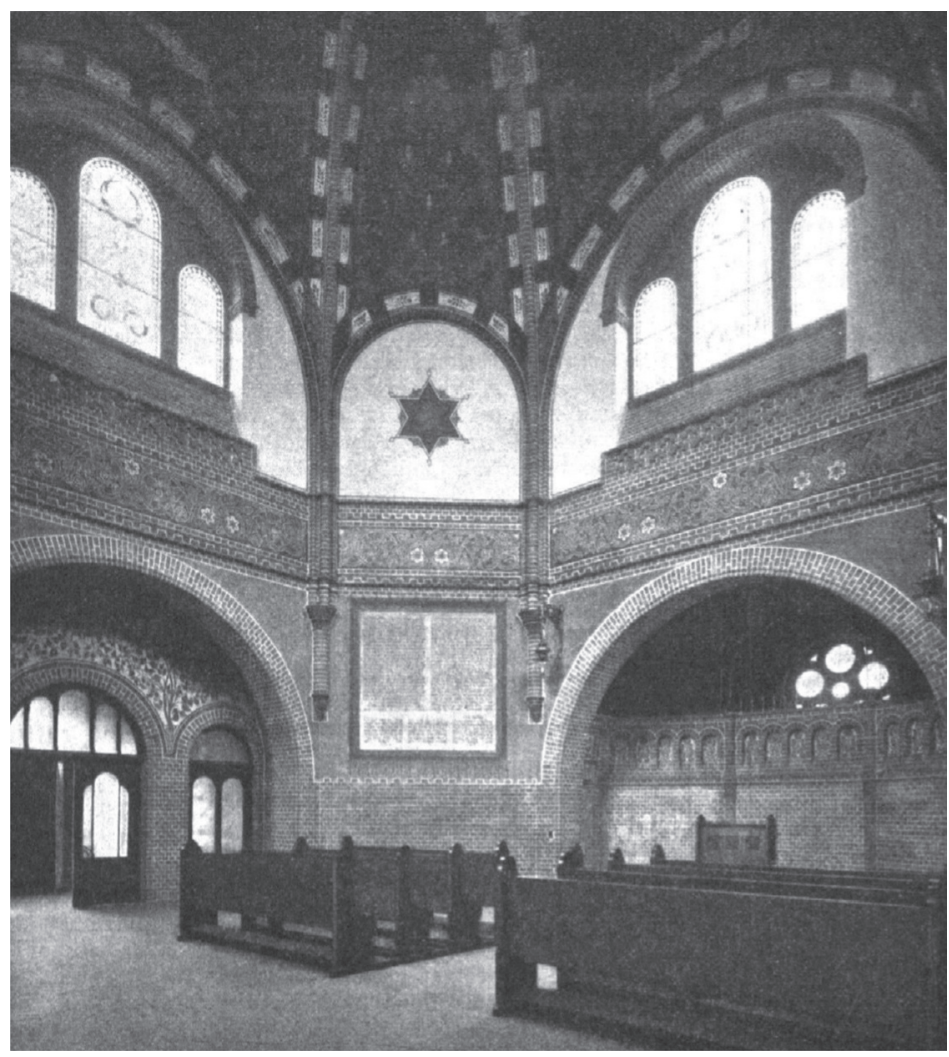

4. The interior of the main hall of the pre-burial house at the new Jewish cemetery in Munich. Architect: Hans Grassel. "Wasmuths Monatshefte für Baukunst” 1918, nos. 6-7, p. 255.

\section{BIBLIOGRAPHY:}

Archiwum Państwowe w Łodzi, Łódzka Gmina wyznaniowa Żydowska [State Archive in Łódź, Jewish Community in Łódź], No. 5.

Berthold-Hilpert Monika (2015) Jüdisches Museum Franken, Fürth [in:] I. Gadowska, ed.; Wielkomiejskie cmentarze żydowskie w Europie Środkowo-Wschodniej, Łódź: Wydawnictwo Hamal.

Chechłowski Kazimierz (1901), O potrzebie u nas domów przedpogrzebowych, “Zdrowie” 1901, no. 1.

Davidson-Kalmar Ivan (2001) Moorish Style: Orientalism, the Jews, and Synagogue Architecture, "Jewish Social Studies", vol. 7, no. 3, pp. 68-00. 
Ehrlich Richard and Paul, Israelitische Friedhofsanlage für Breslau, "Zentralblatt der Bauverwaltung" 1903 , no. 27 , pp. 168-169.

Feinkind Mojżesz (1930) Dzieje Żydów w Piotrkowie i okolicy od czasów najdawniejszych do chwili obecnej, Piotrków Trybunalski: publication financed by the author.

Friedman Filip (1933) Ludność żydowska Łodzi do r. 1863 w świetle liczb, "Kwartalnik Statystyczny”, vol. 10, no. 4, pp. 461- 496.

Gadowska Irmina, Walczak Bartosz (2015), Zabudowa cmentarza [in:] L. Hońdo ed. Cmentarz żydowski w Łodzi, "Monumenta et Memoria”, vol. 1, pp. 53-74.

Głowacki Kazimierz (1984) Urbanistyka Piotrkowa Trybunalskiego. Piotrków - Kielce: Towarzystwo Przyjaciół Piotrkowa Trybunalskiego, Biuro Badań i Dokumentacji Zabytków w Piotrkowie, Kielecki Oddział Pracowni Konserwacji Zabytków.

Grosglik Izrael L.(1877) W sprawie chowania zwłok, "Izraelita”, no 2, pp. 15-16.

Hońdo Leszek (2011) Dom przedpogrzebowy przy żydowskim Nowym Cmentarzu w Krakowie, Kraków: Universitas.

Ignatowski Grzegorz (1987) Poczatki i dzieje "Nowego Cmentarza" Żydowskiego w Łodzi, "Biuletyn Żydowskiego Instytutu Historycznego w Polsce”, no. 3-4, pp. 59-69.

Janczak Julian (1982) Ludność Łodzi przemystowej 1820-1914, Łódź: Uniwersytet Łódzki.

Kempa Andrzej, Szukalak Marek (2002) Żydzi dawnej Łodzi. Słownik Biograficzny, vol. 2, Łódź: Oficyna Bibliofilów.

Kersz Izaak (1999) Szkice z dziejów Gminy Żydowskiej oraz cmentarza w Łodzi, Łódź: Oficyna Bibliofilów.

Knufinke Ulrich (2005) Jüdische Friedhofsbauten um 1800 in Deutschland Architektur als Spiegel

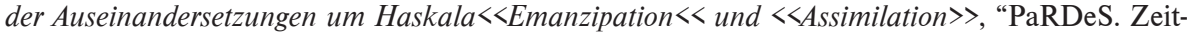
schrift der Vereinigung für Jüdische Studien” 2005, no 2, pp. 68-102.

K. R. (1840) O potrzebie domów przedpogrzebowych, "Przyjaciel Ludu: czyli tygodnik potrzebnych i pożytecznych wiadomości” 1840 , no. 6 .

Knufinke Ulrich (2007) Jewish cemeteries in 19th century Germany between "Tradition"and $<<A s$ similation<<: A paradigmatic development for central Europe? [in:] J. Šiaučiunaitė-Verbickienè, L. Lempertienè, eds., Jewish Space in Central and Eastern Europe. Day-to Day History. Newcastle: Cambridge Scholar Publishing, pp.75-90.

Künzl Hannelore (1999) Jüdische Grabkunst. von der Antike bis heute, Darmstadt: Wissenschaftliche Buchgesellschaft.

Linhof R. A. (1918) Die Kultur der Münchener Friedhofs-Anlagen Hans Grässels. "Wasmuths Monatshefte für Baukunst”, no. 6-7, pp. 199-218. 
Metzler Georg (1911) Die neue Friedhofsanlage [in:] Zur Geschichte der Wormser jüdischen Gemeinde, ihrer Friedhofe und ihres Begräbniswesens, Worms: Kräutersche Buchhandlung, pp. 47-52.

Muszyńscy Danuta and Lech (1995), Cmentarz żydowski w Łodzi, Łódź: Oficyna Bibliofilów.

N.K. (1896) Łódź w sierpniu, "Izraelita”, no. 33.

N.K. (1896) Łódź we wrześniu, "Izraelita”, no. 37.

N.K. (1897) Łódź w październiku, "Izraelita”, no. 43.

Rocznik statystyczny Królestwa Polskiego. Rok 1914, (ed.) W. Grabski, Warszawa: Gebethner and Wolff 1915.

Starkman Adolf (1895) Z Łodzi, "Izraelita”, no. 1.

Stefański Krzysztof (1995) Architektura sakralna Łodzi w okresie przemystowego rozwoju miasta 1820-1914, Łódź: Wydawnictwo Uniwersytetu Łódzkiego.

Walicki Jacek (2000) Synagogi i domy modlitwy w Łodzi, Łódź: Ibidem.

P. Paul (1902) Hermann Konstadt. Ein Gedenkblatt zu seinen 7-jährigen Todestage, "Illustrierte Sonntags Beilage: Handels und Industrieblatt. Neue Lodzer Zeitung”, no. 4, pp. 30-31.

Policya Lekarska. O grzebaniu ciat zmartych (1846), Warszawa: Drukarnia Stanisława Strąbskiego.

Proszyk Jacek (2002) Cmentarz żydowski w Bielsku-Biatej, Bielsko-Biała: Urząd Miejski w Bielsku-Białej. Wydział Kultury i Sztuki.

Reisenthel Amalia (2015) Orientalismus als Mittel zur Identitätsfindung. Sepulkralarchitektur auf dem Jüdischen Friedhof Breslau. Berlin: Lit Verlag.

Stefański Krzysztof (2009) Ludzie, którzy zbudowali Łódź. Leksykon architektów i budowniczych miasta (do 1939 roku), Łódź: Księży Młyn 2009.

Wojewódzki Urząd Ochrony Zabytków w Łodzi [Provincial Office of Monument Preservation in Łódź] No. 406/1; 407/7.

Zbroja Barbara (2005) Miasto umartych. Architektura publiczna Żydowskiej Gminy Wyznaniowej w Krakowie w latach 1868-1939, Kraków: Wydawnictwo WAM.

Żmudzińska-Nowak Magdalena (2006) Dom przedpogrzebowy na nowym cmentarzu żydowskim gliwickie dzieło Maxa Fleischera na tle innych jego realizacji w Europie Środkowej [in:] B. Kubit ed. Żydzi Gliwiccy, Gliwice: Muzeum w Gliwicach, pp. 167-180.

http://www.alemannia-judaica.de/muenchen_friedhof.htm (accessed: 1.01.2018) 


\section{WNĘTRZE DOMU PRZEDPOGRZEBOWEGO NA NOWYM CMENTARZU ŻYDOWSKIM W ŁODZI. UWAGI O ARCHITEK- TURZE, FUNKCJI I STYLU (streszczenie)}

Postęp w zakresie nauk ścisłych, przyrodniczych i medycznych, zapoczątkowany w epoce Oświecenia miał wpływ na wiele obszarów codziennego życia w tym także na stosunek do śmierci i rytuałów pogrzebowych. Zainteresowanie kwestiami ostatecznymi znalazło odzwierciedlenie w zmieniającej się praktyce, która w istotny sposób kształtowała prawne regulacje. Struktura zakładanych od końca XVIII wieku wielkomiejskich cmentarzy żydowskich oraz transformacja znajdującej się w ich granicach architektury ukazują rozwój kultury sepulkralnej, odzwierciedlają funkcjonalne innowacje i zmiany stylowe oraz możliwości i wymagania gmin żydowskich działających w nieżydowskim środowisku. W 19 stuleciu cmentarz staje się miejscem reprezentacyjnym poprzez wprowadzenie nowych rytuałów pogrzebowych, nowoczesnych form pomników nagrobnych, reprezentacyjne budynki i parkowy wygląd. Treść artykułu stanowi analiza wnętrza domu przedpogrzebowego na nowym cmentarzu żydowskim w Lodzi z uwzględnieniem relacji pomiędzy zastosowanymi rozwiązaniami architektonicznymi a przeznaczeniem obiektu oraz powiązań funkcji i stylu. W żydowskim dyskursie historycznym problematyka stylu jako narzędzia manifestacji identyfikacji narodowej lub stopnia akulturacji kojarzona była przede wszystkim $\mathrm{z}$ architekturą synagogalna. Przypadek domu przedpogrzebowego z Łodzi dowodzi, że badanie budynków ceremonialnych, wznoszonych na żydowskich cmentarzach także może pomóc w określeniu kierunku i charakteru kulturowej transformacji.

Słowa kluczowe: cmentarz żydowski, żydowska architektura, Adolf Zeligson, sztuka sepulkralna, architektura w Polsce, domy przedpogrzebowe, styl mauretański

Irmina Gadowska, PhD, graduate of the Department of Art History at the Faculty of Philosophy and History of the University of Lodz, Poland. Since 2004, she has been employed there as a lecturer. Author of the book: "Jewish painters in Lodz in the years 1880-1919" and several articles devoted to the works of Jewish artists in Poland. Supervisor of inventory works at the New Jewish Cemetery in Lodz, author of documentation of monuments preserved from the Jewish cemetery in Brzeziny near Lodz. Member of the Polish Institute for the Study of World Art. 